\title{
АНАЛИЗА НА ПОЛИТИЧКИОТ ДИСКУРС ВО ПРЕДИЗБОРНИТЕ КАМПАЫИ ВО РЕПУБЛИКА МАКЕДОНИЈА И ВО САД
}

Тамара Димоска

„Адамс Едукација ДООЕЛ”- Кичево

tamara.dimoska@hotmail.com

Целта на ова истражување е да се направи критичка анализа на политичкиот дискурс за време на предизборните кампањи во Р. Македонија и во САД. Истражувањето дава увид во манипулативната функција на јазикот и ги претставува начините на кои политичарите во Р. Македонија и во САД ја постигнуваат таа манипулација. За таа цел, беа истражувани вкупно осум говори: четири од македонски (Груевски, Заев, Иванов и Пендаровски) и четири од американски политичари (Обама, Ромни, Буш и Кери). Овој труд ја разгледува структурата на предизборните говори на политичарите во Р. Македонија и во САД од прагматичка гледна точка, односно има за цел да испита колку внимание политичарите посветуваат на креирање на својот став и на вклучување на публиката во дискурсот. До тие сознанија доаѓаме преку испитување на личните заменки.

Клучни зборови: политички дискурс, јазична манипулација, предизборни говори, лични заменки 


\title{
THE ANALYSIS OF POLITICAL DISCOURSE IN PREELECTION CAMPAIGNS IN REPUBLIC OF MACEDONIA AND USA
}

\author{
Tamara Dimoska \\ Adams Education, Kičevo \\ tamara.dimoska@hotmail.com
}

This article's objective is to conduct a critical discourse analysis of political speeches in the Republic of Macedonia and the USA. This research gives an insight into the manipulative function of language and it shows how politicians achieve this manipulation. For this purpose, eight political speeches have been analyzed: four speeches given by Macedonian politicians (Gruevski, Zaev, Ivanov, and Pendarovski) and four given by American politicians (Obama, Romney, Bush, and Kerry). The analysis covers the pragmatic aspect, it examines how much attention the politicians pay to expressing their own opinion and political stances and how they include the audience in their speech. The focus of the analysis is on the personal pronouns.

Key words: political discourse, linguistic manipulation, campaign speeches, personal pronouns 


\section{1 Вовед}

Во овој труд го анализираме дискурсот на политичарите за време на предизборните кампањи. Дискурсот претставува контекстуализиран говор (Chilton and Schäffner 2002; Gee and Handford 2012), односно еден целосен јазичен настан којшто е однапред испланиран и има одредена општествена важност (Lugovaya 2011), како што се, на пример, политичките говори за време на предизборните кампањи. Дискурсот е општествено значаен затоа што со негова помош се отвораат важни прашања поврзани со моќта, а

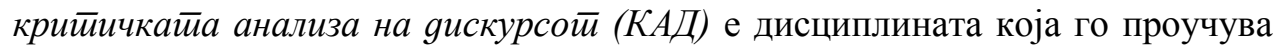
тој однос помеѓу дискурсот и моќта (van Dijk 2001; Wodak 2006; Wodak and Meyer 2001). Дел од крийичкайа анализа на gискурсой е и анализата на политичкиот дискурс. За да го дефинираме политичкиот дискурс, како прво треба да ги идентификуваме луѓето чиј дискурс е предмет на анализа. Во случајов, тоа е усниот или пишаниот дискурс на политичарите, или на политичките институции, како што се: претседателот, премиерот, министрите, членовите на парламентот, или на политичките партии (van Dijk 1997). Политичкиот говор претставува структурирана вербална низа на поврзани говорни чинови изговорени од одредена личност во специфична општествена пригода, со специфична цел, наменети за посебен вид публика (Culpeper et al. 2009). Преку политичкиот дискурс се прикажува политичката моќ, се злоупотребува таа моќ, или, пак, се прикажува доминација. Моќта сама по себе носи контрола на (членови од) една група врз (членови на) друга група. Во нашиот случај станува збор за ментална контрола изразена преку убедување, симулирање, манипулација и други стратегиски начини за влијаење врз мислењето и дејствата на другите. Целта на таквата контрола е да се остварат сопствените интереси со помош на други лица. Политиката претставува еден вид спроведување на моќ. Со оглед на тоа дека политичарите доагаат на власт преку убедување на народот со помош на своите говори, во областа крийичка анализа на gискурсой се јавува гранката

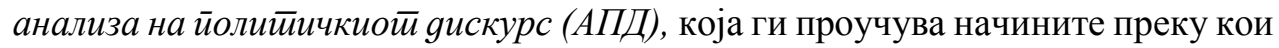
политичарите манипулираат со јазикот со цел да постигнат одреден ефект врз народот (Collet and Najem 2005). Како што можеме да забележиме, овие две дисциплини се тесно поврзани, па оттука можеме да кажеме дека во поширока смисла овој труд спаѓа во областа на крийичкайа анализа на gискурсой, а поконкретно, со оглед на тоа дека фокусот е конкретно на дискурсот на политичарите, трудов претставува дел од областа анализа на

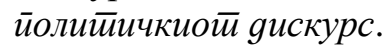

За да дојдат до победа, политичарите се служат со голем број техники за убедување. Интересот за научно проучување на тие техники и нивните ефекти врз публиката е основната мотивација за изработка на овој труд. Се 
истражува начинот на кој политичарите се изразуваат во политичките кампањи и впечатокот којшто го оставаат врз народот. За таа цел, во овој труд направена е анализа на говорите од предизборните кампањи на политичарите од Р. Македонија и од САД и начините на кои кандидатите се претставуваат себеси и ја вклучуваат публиката преку употребата на одредени лични заменки. Личните заменки помагаат во убедувањето на граѓаните да им го дадат својот глас на изборите и токму тие му покажуваат на читателот/слушателот со кого/со што се идентификува политичарот. Со нивна помош политичарите ја претставуваат својата способност да се идентификуваат со интересите и потребите на публиката и на тој начин се прикажуваат себеси како способни лидери на нацијата (Håkansson 2012). Така, на пример, политичарите ја употребуваат личната заменка за прво лице множина ние за да се прикажат себеси како претставници на народот и да побараат согласност и соработка од публиката (Batluk 2011), додека со помош на личната заменка за второ лице множина вие кандидатите ја вклучуваат публиката во дискурсот (Dontcheva-Navratilova 2008).

Политичкиот дискурс е тема на проучување на многу истражувачки трудови низ светот, но малку е проучуван во Р. Македонија, или барем нам тоа не ни е познато. Трудовите кои го проучуваат политичкиот дискурс, главно, се фокусираат на: проучување на стратегиите за убедување и метадискурсните маркери (Bellová 2010; Hyland 1998; Ismail 2012; Донев 2012; Трајкова 2012); анализа на говорите на политичарите во борбата против тероризмот и конструкцијата на gруг̄uо $\bar{u}$, односно изборот на зборови со кои ќе се претстави напаѓачот како терорист, а не како еден од „добрите момци“ (Aghagolzadeh and Bahrami-Khorshid 2009; Coe et al. 2004; Collet and Najem 2005; Daghrir 2013), како и проучување на употребата на личните заменки за да се постигне одреден ефект (Batluk 2011; Bramley 2001; Collet and Najem 2005; De Fina, 1995; Dontcheva-Navratilova 2008, Fernández Martínez and Trujillo González 2012; Karapetjana 2011; Wang 2010). Недостатокот на трудови во нашата држава кои подетално ги проучуваат дискурсните стратегии со чија помош политичарите во Република Македонија и во САД ги користат заменките за креирање на својот став и вклучување на публиката во дискурсот претставува мотивација за спроведување критичка анализа на политичкиот дискурс за време на предизборните кампањи.

По разгледувањето на неколку трудови од оваа област, забележавме дека политичарите во своите инаугуративни говори во голем процент ја вклучуваат публиката во дискурсот и на тој начин својот триумф го споделуваат со присутните (Wang 2010; Fernández Martínez and Trujillo González 2012; Batluk 2011). Токму поради тоа решивме да испитаме дали истото се случува и во нивните предизборни говори. Со оглед на тоа дека целта на говорите одржани за време на предизборните кампањи е да се добијат изборите така што ќе се убеди мнозинството граѓани да гласа за говорителот (Benoit et al. 2003), главната хипотеза која сакаме да ја докажеме 
во овој труд е дека политичарите повеќе внимание посветуваат на креирање на својот став, отколку на вклучување на публиката во дискурсот. Целта на истражувањето е да се види дали политичарите посветуваат повеќе внимание на креирањето на својот став или на вклучувањето на публиката во дискурсот. Истражување во овој труд е спроведено со помош на транскрипти, односно пишани текстови. Корпусот се состои од осум транскрибирани политички говори: четири на политичарите во Р. Македонија и четири на политичарите во САД. Говорите на македонските политичари ги најдовме во аудиоформа на www.youtube.com и ги транскрибиравме, додека говорите на американските политичари ги презедовме од веб-страницата www.presidentialrhetoric.com и ги преведовме.

Македонскиот примерок се состои од четири говори: два говора од парламентарните избори одржани во 2014 год. и два говора од претседателските избори одржани истата година:

a. говорот на Никола Груевски, одржан на 5 април во Скопје, парламентарни избори во Р. Македонија во 2014 година - 5.501 збор;

б. говорот на Зоран Заев, одржан на 6 април во Скопје, парламентарни избори во Р. Македонија во 2014 година - 1.717 зборови;

в. говорот на Ѓорге Иванов, одржан на 5 април во Скопје, претседателска кампања во Р. Македонија во 2014 година - 1.343 зборови; и

г. говорот на Стево Пендаровски, одржан на 21 април во Куманово, претседателска кампања во Р. Македонија во 2014 година - 972 зборови.

Треба да напоменеме дека поради ограничениот број на политички говори кои се достапни во македонските медиуми, немавме голем материјал за избор на располагање, па затоа е присутна значителна зборовна разлика во говорите. Тоа претставува едно од ограничувањата на ова истражување.

Говорите на американските политичари опфаќаат два говора од претседателските избори одржани во 2012 год. и два говора од претседателските избори одржани во 2004 год. и тоа:

а. говорот на Барак Обама, одржан на 19 октомври во Ферфекс, Вирџинија, претседателска кампања во САД во 2012 година - 2.722 зборови;

б. говорот на Мит Ромни, одржан на 2 ноември во Вест Алис, Висконсин, претседателска кампања во САД во 2012 година - 2.483 зборови;

в. говорот на Џорџ Буш, одржан на 19 октомври во Вилиџис, Флорида, претседателска кампања во САД во 2004 година - 4.886 зборови; и 
г. говорот на Џон Кери, одржан на 22 октомври во Милвоки, Висконсин, претседателска кампања во САД во 2004 година - 2.736 зборови.

Во горенаведените осум говори правиме квантитативна анализа, односно ја разгледуваме застапеноста на личните заменки за прво лице еднина, прво лице множина (каде што правиме разлика помеѓу исклучувачко ние: кое го вклучува говорителот и неговите соработници, но не и публиката, и вклучувачко ние: кое ги вклучува говорителот и публиката) и второ лице множина, па ја пресметуваме нивната процентуална застапеност во говорите коишто се предмет на анализа. Предмет на анализа се две стратегии:

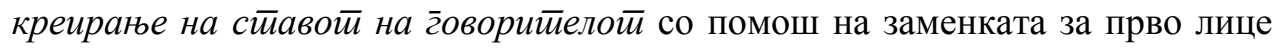
еднина - јас и исклучувачкото ние; и вклучување на йубликайа во gискурсой со помош на вклучувачкото ние и заменката за второ лице множина - вие.

Со оглед на тоа дека анализираме говори со различна должина, во овој труд ја броиме процентуалната застапеност на заменките кои ги исполнуваат горенаведените функции во говорите коишто се предмет на анализа, а не точната бројка на заменки во истите говори. Целта е да се добие објективна слика за зачестеноста на употребата на функциите во прашање. За да се задржи објективноста, анализата на говорите на американските политичари се прави во оригиналните говори на англиски јазик, а не во преводот.

Треба да напоменеме дека во македонскиот јазик категоријата лице освен со лични заменки се изразува и преку личните глаголски форми со помош на личните наставки (Бојковска и др., 2008). Така, на пр. глаголската форма за прво лице еднина е -м (знам), за прво лице множина е -ме (знаеме), а за второ

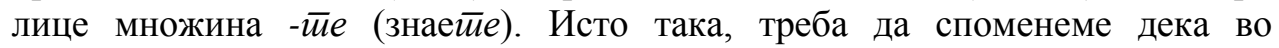
квантитативната анализа не се вклучени одредени случаи на погоренаведените лични заменки, односно:

a. заменките за прво лице еднина со чија помош говорителот пренесува туѓа порака:

She said, fine, just so long as I never have to give a speech.

'Таа кажа, добро, сѐ додека не треба да gржам говори.' (Буш додека пренесува исказ од својата сопруга);

б. заменките за прво лице множина кои го вклучуваат говорителот и неговиот противник:

Прифатии яуел Никола Груевски, 'gа се објасниме' кој вистински ја

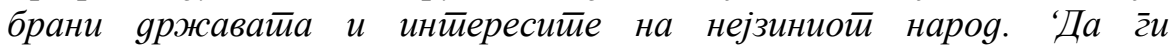

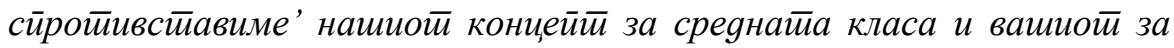
йанамска Макеgонија. (Заев додека го повикува Груевски на дуел);

в. заменките за второ лице множина кои не ја вклучуваат публиката во дискурсот туку имаат или генеричка употреба или говорителот ги употребува за да му се обрати на противникот: 
Are 'you' for equal pay for equal work? Are 'you' for making sure that laws enforce that basic principle?

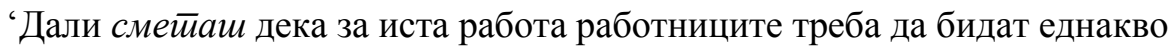
платени? Дали смейаш дека треба да се изгласа закон кој ќе овозможи спроведување на ова основно начело?'(тука Обама не ѝ се обраќа на публиката, туку на Ромни).

Ова истражување ни дава увид во некои од дискурсните стратегии кои политичарите ги користат во своите предизборни говори за да го добијат гласот на граѓаните. Меѓутоа, постојат и доста ограничувања на истражувањето: предмет на анализа се мал број на говори - обработен е само по еден говор од осумте политичари; се разгледуваат говори само од четири предизборни кампањи, две во Република Македонија и две во САД.

\section{2 Анализа на политичкиот дискурс во предизборните кампањи}

Овој дел од трудот е поделен на две поголеми целини: анализа на говорите на политичарите во Р. Македонија и анализа на говорите на политичарите во САД. Во првата целина прво ги анализираме говорите на Никола Груевски, Зоран Заев, Ѓ орге Иванов и Стево Пендаровски, па завршуваме со коментар во кој го споредуваме дискурсот на четворицата политичари. Втората целина ја започнуваме со анализа на говорите на Барак Обама, Мит Ромни, Џорџ Буш и Џон Кери и завршуваме со коментар во кој е извршена споредба на дискурсот на четворицата политичари.

\section{1 Креирање на ставот на говорителот и вклучување на публиката во дискурсот}

Во овој дел од трудот анализираме говори од парламентарните и претседателските избори одржани во Р. Македонија во 2014 год. Треба да напоменеме дека за време на одржувањето на овие предизборни говори, Груевски и Иванов веќе се на власт и на претстојните избори се борат за нов мандат.

Вклучувањето на публиката во дискурсот претставува значаен фактор во градењето на еден убедлив текст затоа што тоа придонесува до суптилно намейнување на ставот на говорителот врз слуштелите (Batluk 2011; Dontcheva-Navratilova 2008; Håkansson 2012; Трајкова 2012). Фокусот на ова истражување е да се утврди која дискурсна стратегија се употребува повеке во анализираните политички говори со цел: 
а. креирање на својот став преку употребата на прво лице еднина и исклучувачкото ние; и/или

б. вклучување на публиката на дискурсот преку употребата на вклучувачкото ние и второ лице множина.

\subsection{1 Прво лице еднина: jac}

Со помош на заменката за прво лице еднина говорителите ја истакнуваат важноста на својот авторитет (De Fina 1995), а исто така и ставаат акцент на своите достигнувања (Bramley 2001). Македонските политичари се обраќаат во прво лице еднина додека говорат за плановите кога ке дојдат на власт, за личното искуство, за ставовите, мислењата, верувањата и сл. Процентуалната застапеност на употребата на личната заменка за прво лице еднина е прикажана во табела 1, а подолу следува и анализа на неколку примери од веќе споменатите говори.

Табела 1. Процентуална застапеност на личната заменка за прво лице еднина јас во говорите на политичарите во Р. Македонија

\begin{tabular}{|l|c|}
\hline \multicolumn{1}{|c|}{ Говорник } & jac \% \\
\hline Иванов & 1,78 \\
\hline Заев & 1,45 \\
\hline Груевски & 0,81 \\
\hline Пендаровски & 0,72 \\
\hline
\end{tabular}

Груевски ѝ се обраќа на публиката во прво лице еднина додека говори за своите лични напори да ја подобри ситуацијата во државата и додека ги пренесува плановите кои ќе ги реализира кога ќе дојде на власт (пример 1). Говорење во прво лице еднина има во $0,81 \%$ од говорот на лидерот на тогашната владејачка партија ВМРО-ДПМНЕ.

(1) ГРУЕВСКИ: Драг̄и йријайели, секој gен г̄о зайочнувам со обиg ga найравам ушиме йовеке за нашайа земја. Сакам йовеке рабойни месйа, сакам йовеке стирански инвесиииии, сакам йоголеми реформи, сакам нови йайишйа зайоа шимо иянинайа може gа бияе üоgобра.

Лидерот на СДСМ говори во прво лице еднина додека ѝ го презентира на публиката своето лично искуство (пример 2). На овој начин, тој всушност си 
го гради својот кредибилитет и им кажува на присутните дека го знае патот до успехот и дека планира истиот да го повтори и кога ке дојде на власт. Застапеноста на првото лице еднина во говорот на Заев изнесува 1,45\%.

ЗАЕВ: Драг̄и ирријайели, со личен иример иоокажав дека йука во Макеgонија може gа се зайочне и gа се усйее йочнувајќи оg

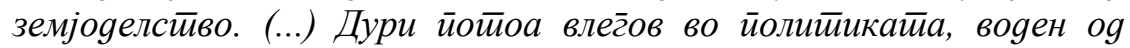
желбайа gа йрияонесам за економски найреgок и благ̄ососииојба на мојой, на нашиой нароg. Не дозволив, и нема gа дозволам, никој gа

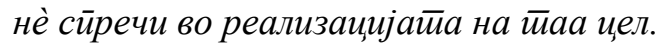

Во пример (3) Иванов ѝ се обраќа на публиката во прво лице еднина и на тој начин се поставува себеси како заштитник и гласноговорник за правата на граѓаните. Тој ја презема целата одговорност врз себе и им кажува на граѓаните дека може да ги изврши задачите кои се дел од претседателската дејност. Иванов говори во прво лице еднина во најголем дел од својот говор, односно во $1,78 \%$.

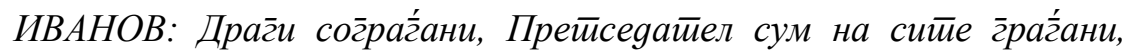

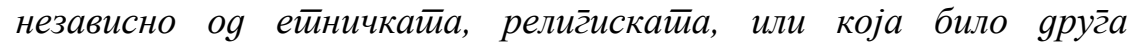

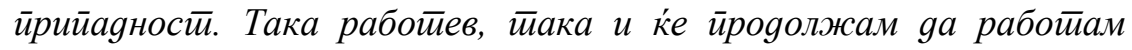
gоколку иовиторно ја добијам вашайа йоggрика.

Преку прво лице еднина, Пендаровски ги кажува своите ставови и очекувања (пример 4). На овој начин тој ја прикажува увереноста дека следуваат подобри резултати во вториот круг од изборите. Обраќањето во прво лице еднина е присутно во $0,72 \%$ од говорот на кандидатот на СДСМ.

ПЕНДАРОВСКИ: 'Очекувам’ gвојно йовеке г̄ласови и за мене и за

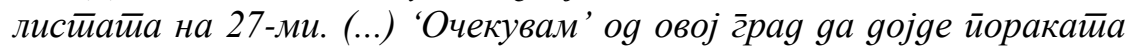
gека сме йобеgиле во цела Макеgонија.

Од погоре прикажаните примери произлегуваат индикации дека од македонските политичари Иванов е тој кој најмногу внимание посветува на претставувањето на себеси, односно најчесто говори во прво лице еднина. Потоа следуваат Заев, Груевски, па Пендаровски. 


\subsection{2 Прво лице множина: исклучувачко ние}

Исклучувачкото ние е заменка за прво лице множина која ги опфаќа говорителот и други индивидуи и/или групи, меѓутоа не и публиката (Scheibman, 2004). Со помош на оваа заменка говорителот се претставува себеси не како индивидуалец, туку како претставник на партијата со која соработува (De Fina, 1995). Дистрибуцијата на оваа заменка во нашиот корпус е прикажана во Табела 2.

Табела 2. Процентуална застапеност на исклучувачкото ние во говорите на политичарите во Р. Македонија

\begin{tabular}{|l|c|}
\hline \multicolumn{1}{|c|}{ Говорник } & исклучувачко ние \% \\
\hline Иванов & 1,71 \\
\hline Заев & 1,51 \\
\hline Груевски & 1,27 \\
\hline Пендаровски & 0,92 \\
\hline
\end{tabular}

Употребата на исклучувачкото ние, ние кое го опфаќа говорителот и неговиот тим, е присутна во $1,27 \%$ од говорот на Груевски. Додека ги опишува минатите дејства и идните планови, Груевски говори во прво лице множина со исклучувачко ние, односно тој говори како претставник на целиот тим од кој е составена Владата на Р. Македонија (пример 5).

ГРУЕВСКИ: Ког̄а 'gојgовме'... ког̄а 'gојgовме' во Влаgайа

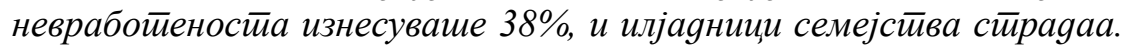
Се зафайивме со битикайа и вистиинскиоти усиеех сииана виялив. (...) 'Имаме' ирецизна аг̄енgа за создавање на овие 64.000 нови рабойни местй.

Заев говори во прво лице множина со исклучувачко ние во $1,51 \%$ од својот говор. Во пример (6) тој говори во името на целата партија додека ги претставува промените направени во СДСМ.

ЗАEВ: Ние во Соиијаляемокрайскиоӣ сојуз знаевме дека ирроменииее во Макеgонија йреба gа йочнай оg ирромениие во йариијайа. (...)

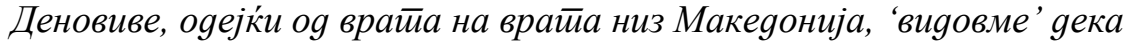
овие наши ирромени йозиииивно се иррифайени секаgе. 
Иванов во пример (7) ја дели заслугата за политичките достигнувања со Владата. Во деловите од говорот каде што тој говори со исклучувачко ние, Иванов се претставува себеси како тимски играч додека говори за своите политички достигнувања, па затоа во овој дел од говорот има зголемена употреба на глаголски форми во прво лице множина. Резултатите од испитувањето на оваа појава укажуваат дека со помош на оваа јазична стратегија Претседателот им кажува на граѓаните дека постои соработка меѓу државниот врв и со тоа Иванов имплицитно ја изразува својата поддршка за тогаш владејачката ВМРО-ДПМНЕ и ги промовира заедничките успеси. ${ }^{1}$ Употреба на исклучувачко ние има во $1,71 \%$ од говорот на Иванов.

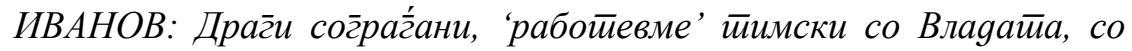

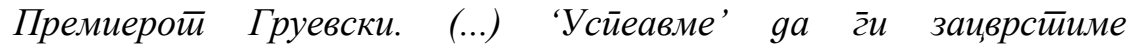

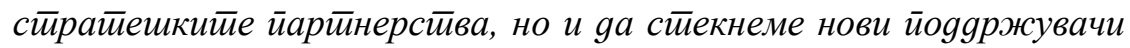
секаgе во свейой. 'Усйеавме' gа обезбеgиме визна либерализащија. 'Усиееавме' gа обезбеgиме нови йазари за макеgонскиие йроизвоgи, нови можностии за макеgонскиие бизнисмени.

Во пример (8), Пендаровски говори во прво лице множина, но не ја вбројува публиката во дискурсот. Тука станува збор за исклучувачко ние во кое спаѓаат говорителот и партијата која стои зад него. Исклучувачкото ние е присутно во $0,92 \%$ од говорот на кандидатот на СДСМ.

ПЕНДАРОВСКИ: Ойозииијайа има многуу йог̄олем кайацийеӣ оg она шиио гоо йокажа во ирвиоти круг̄. 'Ние' само најавивме колкава е

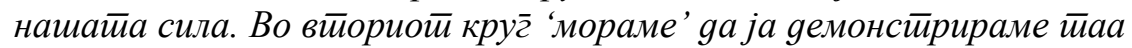

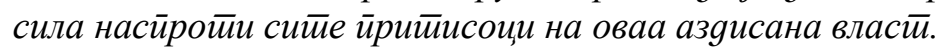

Како што можевме да забележиме во Табела 2 од анализираниот корпус, исклучувачкото ние најчесто беше сретнато кај Иванов. Следуваат Заев, Груевски, па Пендаровски.

\subsection{3 Прво лице множина: вклучувачко ние}

За разлика од исклучувачкото ние, вклучувачкото ние ја внесува и публиката во дискурсот. Оваа заменка придонесува до креирање на чувство на вклученост на присутните во самиот дискурс (Karapetjana 2011). Се смета

\footnotetext{
${ }^{1}$ Претседателската кампања се одвива паралелно со кампањата за парламентарните избори. На денот на одржувањето на вториот круг на претседателските избори, 27 април 2014 година, се одржуваат и парламентарните избори (Димески 2014).
} 
дека политичкиот дискурс е една од областите во кои вклучувачкото ние најчесто се користи за да се манипулира со членството во одредена група, во случајов партијата (Scheibman 2004). Процентуалната застапеност на употребата на вклучувачкото ние е прикажана во табела 3, а подетална анализа следува по табелата.

Табела 3. Процентуална застапеност на вклучувачкото ние во говорите на политичарите во Р. Македонија

\begin{tabular}{|l|c|}
\hline \multicolumn{1}{|c|}{ Говорник } & вклучувачко ние \% \\
\hline Пендаровски & 3,18 \\
\hline Заев & 2,15 \\
\hline Иванов & 0,96 \\
\hline Груевски & 0,36 \\
\hline
\end{tabular}

Во пример (9) претседателот на владејачката партија ја опфаќа и публиката со говорот така што ги повикува присутните да застанат зад ВМРО-ДПМНЕ за да можат сите заедно да остават трага во историјата на државата. Преку употребата на ова вклучувачко ние, Груевски бара солидарност од публиката и тоа го прави во $0,36 \%$ од говорот што е предмет на анализа во овој труд.

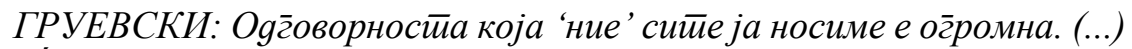

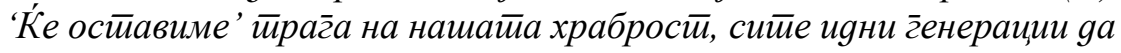
знаай кои 'сме биле' и иито 'сме найравиле'. Вечерва 'йокажуваме' кои сме и за шито 'стиоиме'.

Заев говори во прво лице множина во пример (10) каде ја опфаќа и публиката со дискурсот. Тука, тој говори како граѓанин на Р. Македонија и кажува како граѓаните со здружени сили треба заедно да придонесат за подобра иднина на државата. Вклучувачкото ние е застапено со $2,15 \%$ во говорот на претседателот на СДСМ.

(10) ЗАЕВ: На овие избори, без разлика gали 'сме' ойреgелени или неойреgелени, gали 'сме' Макеgонии, Албанци или Срби, Роми,

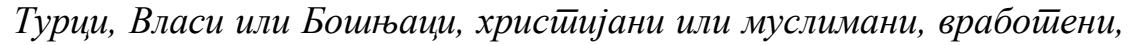

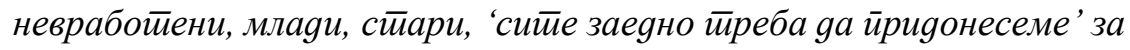
йоgобар живой во нашайа земја Рейублика Макеgонија.

Иванов ја вклучува публиката во дискурсот преку говорење во прво лице множина со вклучувачко ние, како во пример (11). Тука тој се претставува 
себеси како еден од мноштвото Македонци коишто се гордеат со својот главен град. Вклучувачкото ние е застапено во $0,96 \%$ од говорот.

(11) ИВАНОВ: Скойје gенес е вистинска ӣрестиолнина на еgна суверена и независна држава. Грая во кој gосииоинсиивено 'можеме gа

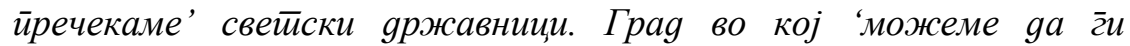

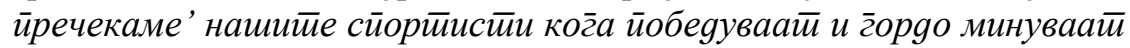
низ йорӣайа Макеgонија.

Додека се обидува да ја мотивира публиката, претседателскиот кандидат на СДСМ говори во прво лице множина (пример 12). На овој начин тој ја поттикнува публиката да учествува во напорите за йоgобра Макеgонија и ѝ префрла дел од одговорноста кажувајќи дека партијата заедно со публиката ја има таа моќ да ја подобри државата. Вклучувачкото ние е застапено во $3,18 \%$ од говорот.

ПЕНДАРОВСКИ: Значи, 'gа остианеме' на куйче, 'gа осйанеме' здружени, со кренатии гллави, 'gа не им ӣойушйаме', бияејќи освен

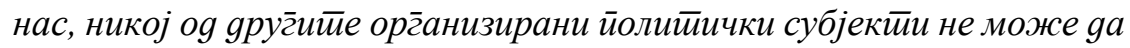
йоgобри - ga gage концейй за йоgобра Макеgонија.

Од четворицата македонски политичари чии говори се предмет на анализа во овој труд, вклучувачкото ние е најчесто употребувано во говорот на Пендаровски. Следуваат Заев, Иванов, па Груевски. Анализата укажува дека членовите на тогашната опозициска партија почесто говорат во прво лице множина со вклучувачко ние, од членовите на владејачката ВМРО-ДПМНЕ. Таков е случајот најверојатно затоа што ним повеќе им е потребна солидарноста и поддршката на народот за да победат на изборите; тие веќе со години наназад се во опозиција и знаат дека им е потребна поддршката на народот повеќе од кога и да е. Од друга страна, пак, Груевски и Иванов веќе ја имаат таа поддршка, нив народот веќе ги изгласал и очекуваат истото да се случи и на тековните избори, па претпоставуваме дека затоа посветуваат помалку внимание на вклучување на публиката во дискурсот.

\subsection{4 Второ лице множина: вие}

Употребата на заменката за второ лице множина им помага на говорителите директно да им се обратат на присутните и да им го привлечат вниманието (Bramley 2001). Процентуалната застапеност на употребата на личната заменка за второ лице множина кај македонските политичари е прикажана во табела 4. 
Табела 4. Процентуална застапеност на личната заменка за второ лице множина вие во говорите на политичарите во Р. Македонија

\begin{tabular}{|l|c|}
\hline \multicolumn{1}{|c|}{ Говорник } & вие \% \\
\hline Пендаровски & 1,33 \\
\hline Груевски & 0,23 \\
\hline Заев & 0,23 \\
\hline Иванов & 0,00 \\
\hline
\end{tabular}

Груевски им се обраќа на граѓаните во второ лице множина во обид да ги мотивира да гласаат и да го направат вистинскиот избор на претстојните избори (пример 13). Премиерот ја опфаќа публиката со говорот обраќајќи ѝ се во второ лице множина во $0,23 \%$ од случаите.

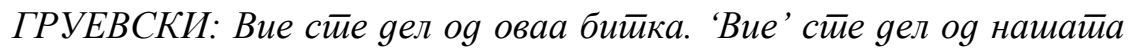
ирриказна. 'Вие' сиете gел оg овие големи ироцеси и gел оg сиие наши

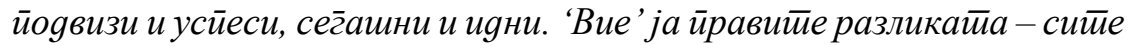

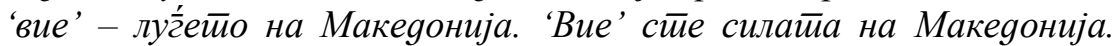
'Вие' стие на ӣот̄ѐ̄.

Вклучување на публиката во дискурсот преку директно обраќање, односно говорење во второ лице множина има само во $0,23 \%$ од говорот на Заев. Таков е случајот со пример (14), каде што лидерот на СДСМ им кажува на присутните дека преку новите реформи кои ги подготвува опозициската партија, самите граѓани ќе бидат дел од законодавната власт на државата.

3АEВ: Ако 'се сомневайе' gека во Р. Макеgонија йовеке не може gа имаме слободоумно размислување и говор, објекииивно судсииво и независни меgиуми, 'верувајтее' - може. (...) Преку нив, 'вие'

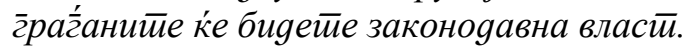

Во некои делови од говорот, претседателскиот кандидат на СДСМ ѝ издава директна заповед на публиката и така ѝ кажува дека тој и партијата која го поддржува се вистинскиот и единствениот избор и дека нема место за дилеми (пример 15). Преку говорење во второ лице множина, публиката е дел од дискурсот во 1,33\% од говорот на Пендаровски.

(15) ПЕНДАРОВСКИ: Немој 'gа се gвоумите', оваа лисйа е gвојно

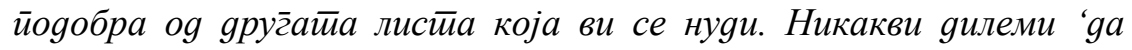
немайе'.

Извршената анализа укажува дека од македонските политичари, Пендаровски најчесто говори во второ лице множина што претпоставуваме 
дека значи дека тој има најголема потреба да го задржи нивното внимание. Тоа до некаде е и очекувано ако се земе предвид дека говорот којшто го анализираме е одржан по првиот изборен круг по кој говорителот влезе како второпласиран со 6,93\% помалку гласови од Иванов (Државна изборна комисија, 2014). Потоа следуваат Груевски и Заев со ист процент на употреба на личната заменка за второ лице множина. Интересно е што во говорот на Иванов нема употреба на оваа лична заменка. Во слично истражување на Де Фина (De Fina 1995) се покажало дека во политичките говори постои недостаток токму на употребата на заменката за второ лице, што укажува дека не постои јасен апел кон слушателите.

\subsection{5 Сумирање на резултатите}

Застапеноста на личните заменки за прво лице еднина, прво лице множина (исклучувачко ние и вклучувачко ние) и второ лице множина во говорите на македонските политичари е прикажана во табела 5.

Табела 5. Процентуална застапеност на личните заменки во говорите на политичарите во Р. Македонија

\begin{tabular}{|c|c|c|c|c|c|}
\hline & Груевски & Заев & Иванов & Пендаровски \\
\hline & & $\%$ & $\%$ & $\%$ & $\%$ \\
\hline \multirow{2}{*}{$\begin{array}{l}\text { креирање на } \\
\text { ставот на } \\
\text { говорителот }\end{array}$} & jac & 0,81 & 1,45 & 1,78 & 0,72 \\
\hline & $\begin{array}{l}\text { исклучувачко } \\
\text { ние }\end{array}$ & 1,27 & 1,51 & 1,71 & 0,92 \\
\hline \multicolumn{2}{|r|}{ Вкупно: } & 2,08 & 2,96 & 3,49 & 1,64 \\
\hline \multirow{2}{*}{$\begin{array}{l}\text { вклучување } \\
\text { на } \\
\text { публиката } \\
\text { во } \\
\text { дискурсот } \\
\end{array}$} & $\begin{array}{l}\text { вклучувачко } \\
\text { ние }\end{array}$ & 0,36 & 2,15 & 0,96 & 3,18 \\
\hline & виe & 0,23 & 0,23 & 0,00 & 1,33 \\
\hline \multicolumn{2}{|r|}{ Вкупно: } & 0,59 & 2,38 & 0,96 & 4,51 \\
\hline
\end{tabular}

Резултатите укажуваат на тоа дека од четворицата политичари чии говори се предмет на анализа во овој труд, само Пендаровски во поголем процент ја вклучува публиката во својот говор. Останатите тројца повеќе внимание посветуваат на креирање и искажување на своите ставови.

Покрај тоа, Иванов е оној кој во најголем процент зборува за себе и за партијата. Според анализата, тој најмногу внимание посветува на креирање на својот став и на опишување на идните планови. 
Исто така, забележуваме дека членовите на тогашната опозициска партија СДСМ посветуваат значително поголемо внимание на вклучување на публиката во дискурсот отколку членовите на владејачката партија. Како што веќе споменавме во анализата, нашите претпоставки се дека ситуацијата е таква затоа што на Заев и на Пендаровски им е попотребна поддршката на публиката, тие се членови на партијата која веќе неколку години наназад губи на изборите, што укажува на недостиг на доверба кај народот. Со опфаќањето на самите гласачи со дискурсот, членовите на СДСМ се обидуваат да се доближат до присутните и да ја вратат нивната доверба. На тој начин тие им даваат до знаење дека се подготвени да работат на поправање на односите со присутните, што имплицитно значи дека се подготвени да работат и на поправање на грешките од минатото.

Како што веќе споменавме, не наидовме на слични истражувања во Република Македонија, па не можеме резултатите од овој дел да ги споредиме со досегашни истражувања на слична тема. Малиот корпус, исто така, претставува едно од ограничувањата на овој труд, па затоа треба да се напомене дека заклучоците во овој дел се изведени само од четирите говори коишто се предмет на анализа.

\section{2 Креирање на ставот на говорителот и вклучување на публиката}

Во овој дел од трудот анализираме говори од претседателските избори во САД одржани во 2012 и 2004 год. Треба да напоменеме дека за време на одржувањето на овие предизборни говори, Обама и Буш веќе се на власт и на претстојните избори се борат за нов мандат.

\subsection{1 Прво лице еднина: јас}

Како што веќе споменавме, политичарите ја користат заменката за прво лице еднина за да ги искажат своите ставови (De Fina 1995; Bramley 2001). После направената анализа за употребата на личната заменка за прво лице еднина во говорите на американските политичари дојдовме до следниве резултати прикажани во табела 6. 
Табела 6. Процентуална застапеност на личната заменка за прво лице јас во говорите на политичарите во САД

\begin{tabular}{|l|c|}
\hline \multicolumn{1}{|c|}{ Говорник } & jac \% \\
\hline Буш & 2,45 \\
\hline Ромни & 2,33 \\
\hline Обама & 1,50 \\
\hline Кери & 1,20 \\
\hline
\end{tabular}

Додека говори за својата политичка замисла Обама ѝ се обраќа на публиката во прво лице еднина (пример 16). На тој начин тој ги убедува слушателите дека има добро разработена програма и мноштво планови кои ќе ги реализира откако ќе дојде на власт. Обраќање во прво лице еднина има во $1,50 \%$ од говорот на кандидатот на Демократската партија.

(16) ОБАМА: 'I' want to send fewer jobs overseas and sell more products overseas. 'I' want to invest in manufacturers and small businesses that create jobs right here in Virginia, right here in America. 'I' want us to control more of our own energy, cut oil imports in half, create thousands of clean energy jobs.

'Сакам да испратам помалку работници, но да продадам повеќе производи во странство. Сакам да инвестирам во производството и во малите бизниси кои отвораат нови работни места токму овде во Вирџинија, токму овде во Америка. Сакам да контролираме повеќе од нашата енергија, да го преполовиме увозот на нафта, да отвориме илјадници нови работни места во областа на зелената енергија.'

Ромни говори во прво лице еднина додека ги набројува своите лични достигнувања (пример 17). Претпоставуваме дека на тој начин кандидатот на републиканците си ги припишува себеси заслугите за постигнатите успеси. Преку обраќањето во прво лице еднина Ромни кажува дека зад себе има големо искуство, нешто што идниот претседател на САД треба да го поседува. Слична појава забележавме и кај кандидатот за премиер на Р. Македонија од тогашната опозициска партија - Заев. Ваквото обраќање е застапено во 2,33\% од говорот на Ромни.

(17) РОМНИ: 'I' built a business, and turned around another. 'I' helped put an Olympics back on track. And with a Democratic legislature, 'I' helped turn my state from deficit to surplus, from job losses to job growth, and from higher taxes to higher take-home pay.

'Изг̄paguв еден бизнис и надградив друг. Помог̄нав во враќањето на Олимпијадата на вистинската патека. И со демократски закон, ѝ 
йомог̄нав на мојата држава од дефицит да дојде во суфицит, од губење на работни места до пораст на работни места, од поголеми даноци до поголема нето-заработувачка.'

Во пример (18), Буш својот став и своите мислења ги искажува преку говорење во прво лице еднина, на тој начин преземајќи целосна одговорност за кажаното. Таквото обраќање е застапено во $2,45 \%$ од говорот.

(18) БУШ: 'I' believe that millions in the Middle East plead in silence for their freedom. 'I' believe women in the Middle East want to live in a free society. 'I' believe the mothers and the fathers of the Middle East want to bring their children up in a free and peaceful world.

'Верувам дека милиони жители на Средниот Исток тивко се молат за својата слобода. Верувам дека жените од Средниот Исток сакаат да живеат во слободно општество. Верувам дека мајките и татковците од Средниот Исток сакаат да ги израснат своите деца во слободен и мирен свет.'

Додека говори за својата предизборна програма, Кери ѝ се обраќа на публиката во прво лице еднина (пример 19). Со прво лице еднина тој го кажува својот став за прашањата кои ги обработува во говорот и остава впечаток дека има добро разработен план и дека знае што ќе прави кога ќе дојде на власт. Кери говори во прво лице еднина во 1,20\% од случаите.

КЕРИ: 'I' will fight a tougher, smarter, more effective war on terror. (...) 'I' will not privatize Social Security. 'I' will not cut benefits. And 'I' will not raise the retirement age.

'Ke воgам посилна, попаметна, поефикасна војна против тероризмот. (...) Нема ga гоo йривайизирам Социјалното осигурување. Нема gа ги укинам паричните надоместоци. И нема ga ја зголемам возраста за пензионирање.'

Од четворицата политичари чии говори се предмет на анализа во овој труд, Буш најчесто говори во прво лице еднина. Следуваат Ромни, Обама, па Кери. Резултатите упатуваат на тоа дека членовите на Републиканската партија почесто ја користат личната заменка за прво лице еднина од членовите на Демократската партија. 


\subsection{2 Прво лице множина: исклучувачко ние}

Со исклучувачкото ние не се опфаќа публиката во говорот, туку политичарите говорат за себе и за своите соработници (Scheibman 2004). Процентуалната застапеност на употребата на исклучувачкото ние во говорите на американските политичари е прикажана во табела 7.

Табела 7. Процентуална застапеност на исклучувачкото ние во говорите на политичарите во САД

\begin{tabular}{|l|c|}
\hline \multicolumn{1}{|c|}{ Говорник } & исклучувачко ние \% \\
\hline Обама & 0,95 \\
\hline Кери & 0,87 \\
\hline Буш & 0,79 \\
\hline Ромни & 0,56 \\
\hline
\end{tabular}

Во пример (20) Обама говори во прво лице множина со исклучувачко ние, заменка која го опфаќа говорителот и луѓето со кои тој соработува, но не и публиката. Претседателот го користи исклучувачкото ние за да каже дека има соработници кои му помагаат во реализацијата на неговите планови. Исто така, исклучувачкото ние му помага да се претстави себеси како човек кој е способен за соработка и кој знае да им оддаде признание на своите соработници. Обраќањето во прво лице множина со исклучувачко ние е застапено во $0,95 \%$ од говорот на Обама.

(20) ОБАМА: The only person who should decide about your health care is you. And, by the way, that's why 'we' fought so hard to pass health care reform, a.k.a. Obamacare. That's why 'we' pushed for it.

'Единствена личност која треба да одлучува за вашата здравствена нега сте вие. Впрочем, затоа се боревме толку за да помине реформата за здравствена нега, позната како Обамакер. Затоа ирравевме толку големи напори.'

Ромни говори со исклучувачко ние во пример (21). Преку говорење во прво лице множина, тој ја истакнува својата расположеност за соработка и кажува како со тимска работа ќ ја подобри ситуацијата во државата. Со говорење со исклучувачко ние се среќаваме во $0,56 \%$ од говорот на Ромни. 
(21) РОМНИ: When I am elected, 'we' will change course on energy. (...) 'We' can help hold down prices at the pump and grow new energy jobs and manufacturing jobs.

'Кога ќе дојдам на власт, ќе г̄o иромениме третманот на енергијата. (...) Ḱ йомог̄неме да се намалат цените на горивото и ќе отвориме нови работни места во секторот на енергијата и рачното производство.'

Кога говори за плановите кои треба да се реализираат откако говорителот ќе дојде на власт, Буш им се обраќа на присутните во прво лице множина (пример 22). На тој начин ја дели одговорноста за идните планови со своите соработници и својот тим. Буш го користи исклучувачкото ние во $0,79 \%$ од говорот.

БУШ: In a new term, 'we' will make sure every poor county in America has a community health center. 'We' will do more to make sure poor children are fully subscribed in our programs for low-income families.

'Во новиот мандат, ќе обезбеgиме општински здравствен центар во секоја посиромашна населба во Америка. Ќе найравиме повеќе за да можат сите сиромашни дечиња да добиваат добротворен прилог од нашите програми за семејства со ниски приходи.'

Во пример (23) Кери говори во прво лице множина со исклучувачко ние. Со фразата we believe (ние веруваме) тој не ја вклучува публиката во дискурсот, туку говори во свое име и во името на тимот кој стои зад него. На тој начин, Кери не ги искажува само верувањата на неговите соработници, туку и ја промовира својата политичка замисла. Обраќањето со исклучувачко ние е застапено во $0,87 \%$ од говорот.

КЕРИ: 'We' believe that the middle class is the backbone of this country - and that hard-working women are the bedrock of our families. 'We' believe that women deserve more than false assurances and empty promises from their President.

'Веруваме дека средната класа е столбот на оваа држава - и дека вредните жени се темелот на нашите семејства. Веруваме дека жените заслужуваат повеќе од лажни уверувања и празни ветувања од нивниот претседател.'

Исклучувачкото ние е најзастапено во говорот на Обама. Потоа следуваат Кери, Буш, па Ромни. Од горе прикажаното произлегуваат индикации дека кандидатите на Демократската партија повеќе го користат исклучувачкото ние од кандидатите на Републиканската партија, што значи дека демократите 
посветуваат повеќе време на креирање на својот став, отколку на вклучување на публиката во дискурсот.

\subsection{3 Прво лице множина: вклучувачко ние}

Веќе беше споменато дека личната заменка за прво лице множина може да има и вклучувачки ефект, односно да ја опфаќа и публиката (Karapetjana 2011). Зачестеноста на употребата на вклучувачкото ние во говорите на американските политичари е илустрирана во Табела 8.

Табела 8. Процентуална застапеност на вклучувачко ние во говорите на политичарите во САД

\begin{tabular}{|l|c|}
\hline \multicolumn{1}{|c|}{ Говорник } & вклучувачко ние \% \\
\hline Ромни & 1,08 \\
\hline Обама & 1,06 \\
\hline Буш & 0,65 \\
\hline Кери & 0,43 \\
\hline
\end{tabular}

Во пример (24) ја гледаме употребата на вклучувачкото ние, заменка која ги опфаќа и говорителот и слушателите (во случајов граѓаните). Во овој пример можеме да забележиме дека покрај возвишување на себеси имаме и напад на личноста на противникот. Обама говори за лошите политики на Ромни не како претседателски кандидат туку како граѓанин на САД и, всушност, го претставува гласот на народот додека ги делегитимизира политиките на противникот. Ваквото обраќање е присутно во 1,06\% од говорот.

(24) ОБАМА: I've met too many good Americans who work so hard, show so much resilience, so much resolve - we have been fighting our way back from some of the same policies he's advocating. 'We' have been there. 'We' have tried it. 'We' can't go back. 'We' are moving forward.

'Имам запознаено многу добри Американци кои работат напорно, покажуваат голема издржливост, голема решителност - сите ние заедно се боревме да го пронајдеме излезот од истите тие политики за кои тој се залага. Бевме таму. Го йробавме тоа. Не смееме да се враќаме назад. Oguмe напред.' 
Ромни говори во прво лице множина во пример (25). Овојпат со дискурсот е опфатена и публиката. Кандидатот на републиканците се става себеси во улогата на граѓанин на САД и ја претставува ситуацијата во државата од перспектива на граѓаните. Тој им кажува на присутните да не се обесхрабруваат затоа што ако го изберат вистинскиот човек да ја води државата можат да направат сѐ. Со прво лице множина, Ромни се обидува да ги мотивира граѓаните да го направат вистинскиот избор и да гласаат за него. Публиката станува дел од дискурсот со вклучувачко ние во 1,08\%.

(25) РОМНИ: If there is anyone worried the last four years are the best 'we' can do, if there is anyone who fears that the American dream is fading away, if there is anyone who wonders whether better jobs and better paychecks are things of the past, I have a clear and unequivocal message: with the right leadership, America will come roaring back. 'We' are Americans. 'We' can do anything.

'Доколку некој е загрижен дека во претходните четири години го gagoвме најдоброто од себе, доколку некој се плаши дека американскиот сон тивко умира, доколку некој се прашува дали подобрите работни места и подобрите плати се минато, имам јасна и недвосмислена порака: со помош на вистинско водство, Америка ќe се врати во голем стил. Ние сме Американци. Можеме да направиме сѐ.'

Публиката е дел од дискурсот на Буш додека тој се претставува себеси како еден од мноштвото Американци кои се водат по истите принципи и се залагаат за истите цели (пример 26). Во овој случај станува збор за употреба на вклучувачко ние кое го има во $0,65 \%$ од говорот.

(26) БУШ: This economy of ours is moving forward, and 'we' are not going to go back to the days of tax and spend. (...) In a time of change, 'we' must support the institutions that give our lives direction and purposeour families, our schools, our places of worship.

'Оваа наша економија се движи напред и нема ga се враќаме назад во деновите кога преовладуваа даноци и давачки. (...) Во време на промени, мораме да ги поддржиме институциите кои му даваат насока и цел на нашиот живот - нашите семејства, нашите училишта, нашите места за богослужба.'

Кери ја опфаќа публиката со дискурсот говорејќи во прво лице множина во пример (27). Тука, тој се поистоветува со нив и станува еден од Американците на кои им е потребен претседател со карактеристиките коишто ги опишува. Претставувајќи се себеси како жител на САД, а не како 
претседателски кандидат, Кери им кажува на присутните дека за себе не посакува ништо повеќе од она што им го посакува ним: йрейсеgайел кој г̄o

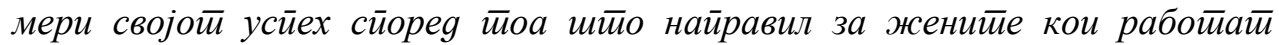
найорно. Покрај тоа што се легитимизира себеси, во овој пример Кери го

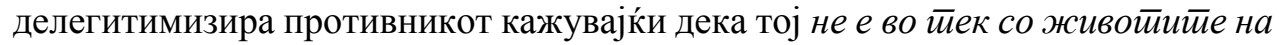

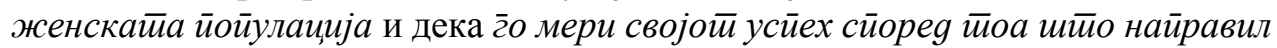
за најимойливитее. Кери говори со вклучувачко ние во $0,43 \%$ од својот говор.

КЕРИ: In eleven days, 'we' face a fundamental choice. Do 'we' want four more years of a President who's out of touch with women's lives and measures his success by how much he's done for those with the most? Or do 'we' want a fresh start with a President who measures progress by what he's done to help women who work hard at a job-and who work at the most important job of all, raising our children.

'За единаесет дена се соочуваме со многу важен избор. Сакаме ли уште четири години да имаме претседател кој не е во тек со животите на женската популација и кој го мери својот успех според тоа што направил за најимотливите? Или сакаме нов почеток со претседател кој го мери својот успех според тоа што направил за жените кои работат напорно - и кои ја имаат најважната работа од сите, подигањето на нашите деца.'

Можеме да забележиме дека вклучувачкото ние најмногу го користи Ромни во својот говор. Следуваат Обама, Буш, па Кери. Прикажаните резултати укажуваат дека кандидатите во понеодамнешните избори во поголем процент ја користат оваа лична заменка споредено со кандидатите од изборите во 2004 год.

\subsection{4 Второ лице множина: вие}

Со помош на личната заменка за второ лице множина се испраќа апел до публиката и на тој начин се насочува вниманието на присутните кон говорителот (Bramley, 2001). Процентуалната застапеност на употребата на личната заменка за второ лице множина кај политичарите од САД е прикажана во табела 9. 
Табела 9. Процентуална застапеност на личната заменка за второ лице множина вие во говорите на политичарите во САД

\begin{tabular}{|l|c|}
\hline \multicolumn{1}{|c|}{ Говорник } & вие \% \\
\hline Обама & 0,91 \\
\hline Кери & 0,76 \\
\hline Ромни & 0,56 \\
\hline Буш & 0,42 \\
\hline
\end{tabular}

Обама ги претставува разликите во програмите на двајцата претседателски кандидати преку говорење во второ лице множина (пример 28). На тој начин тој се дистанцира од својата позиција како претседателски кандидат и остава впечаток дека субјективно ги презентира тие дистинкции. Истовремено, тој ја префрла одговорноста за иднината на државата во рацете на граѓаните и им ја дава моќта да одлучат во која насока ќе се движи нивната држава во наредните четири години. Обама директно им се обраќа на граѓаните во $0,91 \%$ од својот говор.

(28) ОБАМА: Eighteen days and 'you' are going to step into a voting booth. And 'you' are going to have a very big choice to make. (...) And in 18 days, 'you' are going tohave a chance to say whether we keep moving forward.

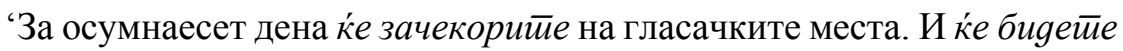
соочени со голем избор. (...) И за 18 дена ќе имайе шанса да кажете дали ќе продолжиме да се движиме напред.'

Ромни испраќа апел до публиката преку говорење во второ лице множина во $0,56 \%$ од својот говор. Исто како Обама и тој ја става одговорноста за изборот на вистинскиот кандидат во рацете на граѓаните и им кажува дека тие се оние кои одлучуваат во кој правец ќе се движи државата, односно дали

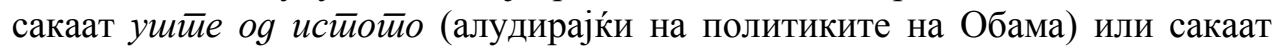
вистиински иромени (претставувајќи се себеси како човек кој ќе ги донесе тие промени) (пример 29).

(29) РОМНИ: The question of this election comes down to this: do 'you' want more of the same or do 'you' want real change?

'Прашањето на овие избори се сведува на следново: сакайе ли уште од истото или сакайе вистинска промена?'

Во говорот на Буш граѓаните стануваат дел од дискурсот така што тој им се обраќа на присутните преку говорење во второ лице множина и на тој начин им кажува што треба да направат за да имаат йобезбеgна, йосилна и 
йоgобра Америка (пример 30). Говорењето во второ лице множина е застапено во $0,42 \%$ од говорот на Буш.

БУШ: 'You' need to go to your friends and neighbors. (...) When 'you' get them headed to the polls, remind them, if they want a safer America, a stronger America, a better America, to put me and Dick Cheney back in office.

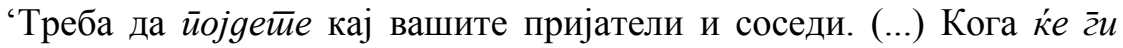
убеguйе да излезат на гласање, потсетете ги, доколку сакаат побезбедна Америка, посилна Америка, подобра Америка, да нѐ вратат мене и Дик Чејни на власт.'

Во пример (31) Кери ѝ се обраќа на публиката во второ лице множина. Како и останатите кандидати, така и Кери на тој начин им ја дава моќта за одлучување на присутните и им кажува дека тие се оние кои треба да го направат изборот меѓу кандидатите. Говорењето во второ лице множина е присутно во $0,76 \%$ од говорот.

(31) КЕРИ: If 'you' give me that chance - I will be that President. (...) 'You' don't have to settle for more of the same.

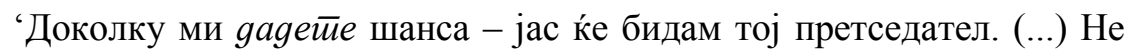
мора да се заgоволийе со повеќе од истото.’

Горенаведените податоци укажуваат дека од четворицата политичари Обама најмногу ја користи личната заменка за второ лице множина; потоа следуваат Кери, Ромни, па Буш. Анализираните говори нѐ упатуваат да донесеме заклучок дека членовите на Демократската партија повеќе ја вклучуваат публиката во дискурсот преку директно обраќање, отколку членовите на Републиканската партија, но тоа не можеме да го тврдиме со оглед на малобројниот корпус.

\subsection{5 Сумирање на резултатите}

Застапеноста на личните заменки за прво лице еднина, прво лице множина (исклучувачко ние и вклучувачко ние) и второ лице множина во говорите на американските политичари е прикажана во табела 10. 
Табела 10. Процентуална застапеност на личните заменки во говорите на политичарите во САД

\begin{tabular}{|c|c|c|c|c|c|}
\hline & Обама & Ромни & Буш & Кери \\
\hline & & $\%$ & $\%$ & $\%$ & $\%$ \\
\hline \multirow{2}{*}{$\begin{array}{l}\text { креирање на } \\
\text { ставот на } \\
\text { говорителот }\end{array}$} & jac & 1,50 & 2,33 & 2,45 & 1,20 \\
\hline & $\begin{array}{l}\text { исклучувачко } \\
\text { ние }\end{array}$ & 0,95 & 0,56 & 0,79 & 0,87 \\
\hline \multicolumn{2}{|r|}{ Вкупно: } & 2,45 & 2,89 & 3,24 & 2,07 \\
\hline \multirow{2}{*}{$\begin{array}{l}\text { вклучување } \\
\text { на } \\
\text { публиката во } \\
\text { дискурсот }\end{array}$} & $\begin{array}{l}\text { вклучувачко } \\
\text { ние }\end{array}$ & 1,06 & 1,08 & 0,65 & 0,43 \\
\hline & вue & 0,91 & 0,56 & 0,42 & 0,76 \\
\hline \multicolumn{2}{|r|}{ Вкупно: } & 1,97 & 1,64 & 1,07 & 1,19 \\
\hline
\end{tabular}

Од табелата 10 индикативно е дека сите четворица политичари повеќе внимание посветуваат на креирањето на својот став и презентирањето на идните планови, отколку на вклучување на публиката во дискурсот. До истите индикации е дојдено и во истражувањето на Håkansson (2012) која ги истражува говорите на американските претседатели Обама и Буш. Wang (2010) ги истражува личните заменки во победничкиот и инаугуративниот говор на Обама и доаѓ до заклучок дека Обама повеќе внимание посветува на користење на заменките за прво лице еднина и множина, отколку на оние за второ - за директно обраќање на публиката, додека анализата на инаугуративниот говор на Обама од страна на Batluk (2011) покажува дека тогашниот претседател на САД во голема мерка ја вклучува публиката во дискурсот со вклучувачкото ние. Истражувањето на победничките говори на Обама и Буш спроведено од страна на Фернандез Мартиннез и Трухиљо Гонзалез (Fernández Martínez \& Trujillo González 2012) го носи истиот заклучок дека Обама го дели својот триумф со публиката така што и нив ги вклучува во говорот, додека, пак, Буш не ѝ дава никаква значајна улога на публиката.

\section{4 Заклучок}

Во истражувањето се потврди главната хипотеза дека политичарите повеќе внимание посветуваат на креирање на својот став, отколку на вклучување на публиката во дискурсот.

Деталните податоци за процентуалната застапеност на личните заменки за креирање на ставот на говорителот и оние за вклучување на публиката во дискурсот се прикажани во табела 11. 
Табела 11. Споредба на процентуалната застапеност на личните заменки

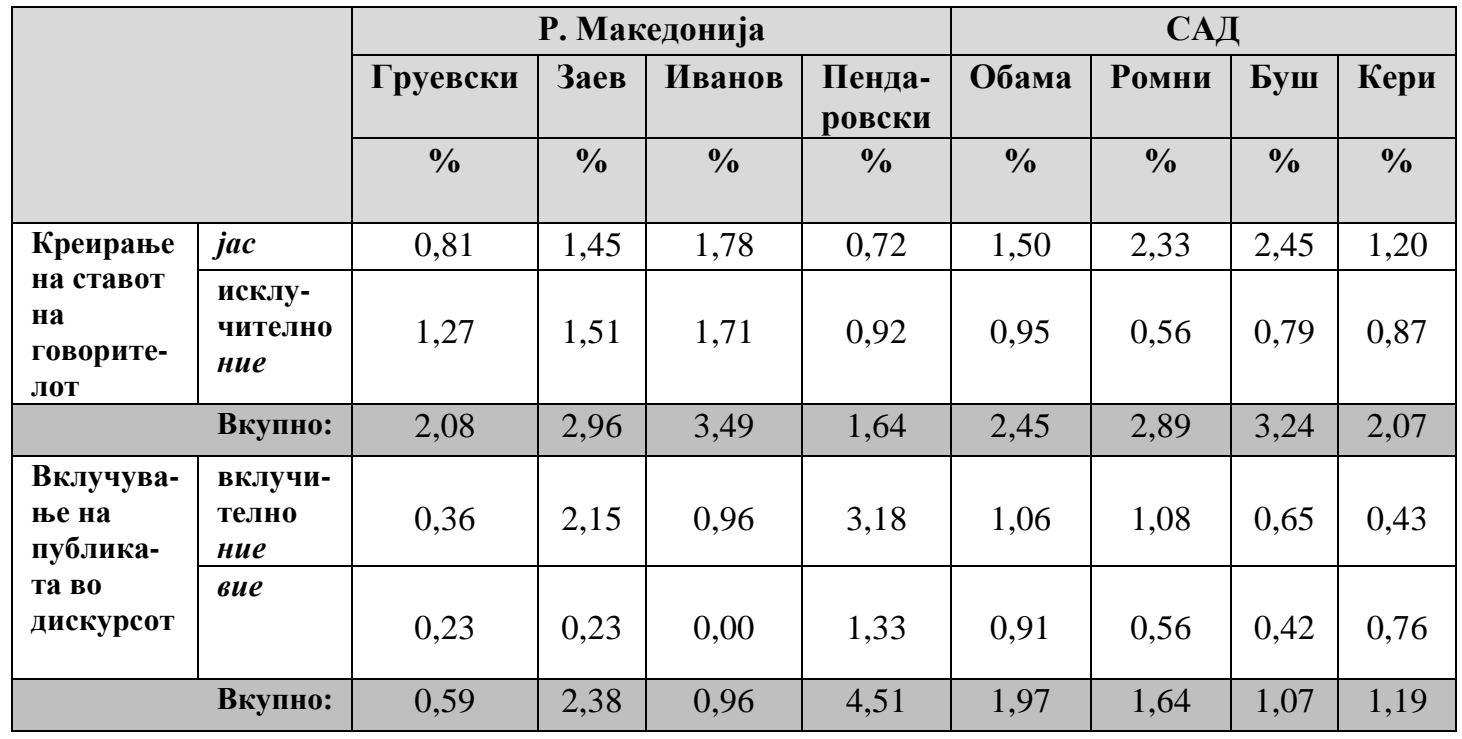

Споредбата меѓу говорите на осумте политичари покажува дека нема сличности во процентуалната застапеност на личните заменки во говорите на победниците, но има определени културолошки карактеристики кои вреди да се спомнат. Така, од направената анализа произлегуваат следниве индикации:

а. членовите на опозициската партија во Р. Македонија посветуваат значително поголемо внимание на вклучување на публиката во дискурсот отколку членовите на владејачката партија, додека во САД сите четворица политичари повеќе внимание посветуваат на креирањето на својот став и презентирањето на идните планови, отколку на вклучување на публиката во дискурсот;

б. политичарите во двете држави посветуваат повеќе внимание на креирање на својот став, отколку на вклучување на публиката во дискурсот;

в. политичарите во САД посветуваат поголем процент од говорот на креирање на својот став, отколку политичарите во Р. Македонија; и

г. политичарите во Р. Македонија посветуваат поголем процент од говорот на вклучување на публиката во дискурсот, отколку политичарите во САД.

Уште еднаш напоменуваме дека ова истражување е направено врз мал корпус и затоа не можат да се извлечат генерализирани заклучоци. Потребни 
се дополнителни истражувања на многу повеќе говори за да се потврди или побие погоре изнесеното.

\section{Библиографија}

Бојковска, С., Минова-Ѓ уркова, Л., Пандев, Д., Цветковски, Ж. (2008). Оӣшӣa грамайика на макеgонскиой јазик. Скопје: Просветно дело АД.

Димески, Ј. (2014). Прирачник за йарламенйарни избори во Рейублика Макеgонија 2014 г̄oguна. Скопје: Фондација Конрад Аденауер во Република Македонија.

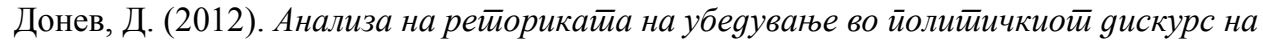
макеgонски и на анг̄лиски јазик. Магистерски труд. Скопје: Универзитет „Св. Кирил и Методиј”.

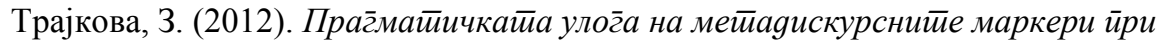

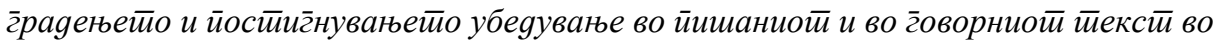

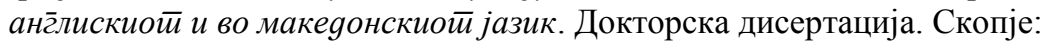
Универзитет „Св. Кирил и Методиј”.

Aghagolzadeh, F., and Bahrami-Khorshid, S. (2009). Language as a puppet of politics: a study of McCain's and Obama's speech on Iraq War, a CDA approach. International Journal of Criminology and Sociological Theory, 2: 218-29.

Batluk, L. (2011). Rhythm and rhetoric: a linguistic analysis of Obama's inaugural address. Bachelor's thesis. Sweden: Halmstad University.

Bellová, H. (2010). The Evolution of means of persuasion: discourse analysis of sample inaugural speeches of US presidents 1833-1997. Bachelor's thesis. Brno: Masaryk University.

Benoit, W. L., McHale, J. P., Hansen, G. J., Pier, P. M. and McGuire, J. P. (2003). Campaign 2000, a functional analysis of presidential campaign discourse. Oxford: Rowman \& Littlefield Publishers.

Bramley, N. R. (2001). Pronouns of Politics: the use of pronouns in the construction of 'Self' and 'Other' in political interviews. Преземено од: https://openresearch-repository.anu.edu.au/bitstream/1885/46225/5/01 front.pdf

Coe, K., Domke, D., Graham, E. S., Lockett John, S., and Pickard, V. (2004). No shades of gray: the binary discourse of George W. Bush and an echoing press. Journal of Communication, 54: 234-252.

Collet, T., Najem, T. (2005). Word Choices in Post-9/11 Speeches and the Identity Construction of the Other. Retrieved from: http://www.cpsa-acsp.ca/papers2005/najem.pdf.

Chilton, P. A. and Schäffner, C. (eds.). (2002). Politics as Text and Talk, analytical approaches to political discourse. Norwich: John Benjamins.

Culpeper, J., Katamba, F., Kerswill, P., Wodak, R. and McEnery, T. (eds.). (2009). English Language, Description, Variation and Context. London: Palgrave Macmillan.

Daghrir, W. (2013). Binary discourse in U.S. presidential speeches from FDR to Bush. Journal of Applied Physics, 5: 25-36. 
De Fina, A. (1995). Pronominal choice, identity and solidarity in political discourse. Interdisciplinary journal for the study of discourse text, 15 (3): 379-410.

Dontcheva-Navratilova, O. (2008). Functions of Self-reference in diplomatic Addresses. Discourse and Interaction, 1 (1): 7-24.

Fernández Martínez, D. and Trujillo González, V. C. (2012). Obama and Bush: their victory and non-victory speeches. Onomázein, 1: 205-217.

Gee, J.P., and Handford, M. (eds.). (2012). The Routledge handbook of discourse analysis. Oxon: Routledge.

Håkansson, J. (2012). The Use of Personal Pronouns in Political Speeches: A comparative study of the pronominal choices of two American presidents. Bachelor's thesis. Växjö: Linnæus University.

Hyland, K. (1998). Persuasion and context: The pragmatics of academic metadiscourse. Journal of Pragmatics, 30: 437-55.

Ismail, H. M. (2012). Discourse markers in political speeches: forms and functions. Journal Of College Of Education For Women. 23 (4): 1260-1278.

Karapetjana, I. (2011). Pronominal Choice in Political Interviews. Baltic Journal of English Language, Literature and Culture, 1: 36-45.

Lugovaya, N. (2011). Discourse analysis. The notion of speech event. Retrieved from: http://www.rostov-language.ru/help-36.html\#2. The_notion_'speech_event'.

Scheibman, J. (2004). Inclusive and exclusive patterning of the English first person plural: evidence from conversation. In M. Achard and S. Kemmer (eds.). Language, culture and mind, 378-396. Stanford, CA: CSLI Publications.

Van Dijk, T. A. (2001). Critical discourse analysis. Bo D. Tannen, D. Schiffrin and H. Hamilton (eds.). Handbook of Discourse Analysis, 352-371. Oxford: Blackwell.

Wang, J. (2010). A critical discourse analysis of Barack Obama's speeches. Journal of Language Teaching and Research, 1: 254-61.

Wodak, R. (2006). Handbook of pragmatics. Amsterdam/Philadelphia: John Benjamins.

Wodak, R., and Meyer, M. (eds.). (2001). Methods of critical discourse analysis. Surrey: SAGE Publications Ltd.

Presidential rhetoric. (2004, October 19). George Bush: Campaign Remarks in Florida. http://www.presidentialrhetoric.com/campaign/speeches/bush_oct19.html.

Presidential rhetoric. (2004, October 22). John Kerry: Campaign Remarks in Milwaukee. http://www.presidentialrhetoric.com/campaign/speeches/kerry_oct22.html.

Presidential rhetoric. (2012, October 19). Barack Obama: "Romnesia": Campaign Stop in Virginia. http://presidentialrhetoric.com/campaign2012/obama/10.19.12.html.

Presidential rhetoric. (2012, November 2). Mitt Romney: Campaign Remarks in Wisconsin. http://presidentialrhetoric.com/campaign2012/romney/11.02.12.html.

YouTube. (2014, April 5). Мийинг̄ во Скойje. https://www.youtube.com/watch?v=WJQBIsF5FXU.

YouTube. (2014, April 6). Zoran Zaev: Miting Pela. https://www.youtube.com/watch?v=owcl9yBklNA.

YouTube. (2014, April 21). Стево Пендаровски - Митинг на СДСМ во Куманово. https://www.youtube.com/watch?v=_QdmIO-pNts. 